\title{
FOOD POISONING PREVENTION DURING DINING OUT: A PRELIMINARY STUDY OF KNOWLEDGE, ATTITUDE, PRACTICE AND PERCEPTION AMONG CONSUMERS AT A SELECTED RURAL AREA IN TERENGGANU
}

\author{
NUR AFIFAH MURSYIDA ZAUJAN ${ }^{1}$, ASMA' ALI $^{1 *}$, MALINA OSMAN ${ }^{2}$, HUI YEE CHEE ${ }^{2}$, \\ NUR RAIHANA ITHNIN ${ }^{2}$, NORASHIQIN MISNI ${ }^{2}$, SURIANTI SUKERI ${ }^{3}$ and CHRISTIE PEI-YEE CHIN ${ }^{4}$ \\ ${ }^{1}$ Faculty of Fisheries and Food Science, Universiti Malaysia Terengganu, \\ 21030 Kuala Nerus, Terengganu, Malaysia \\ ${ }^{2}$ Department of Medical Microbiology and Parasitology, Faculty of Medicine and Health Sciences, \\ Universiti Putra Malaysia, 43400 Serdang, Selangor Darul Ehsan, Malaysia \\ ${ }^{3}$ Department of Community Medicine, School of Medical Sciences, Universiti Sains Malaysia, \\ 16150 Kota Bharu, Kelantan, Malaysia \\ ${ }^{4}$ Faculty of Computing and Informatics, Universiti Malaysia Sabah, \\ 88300 Kota Kinabalu, Sabah, Malaysia \\ *E-mail: asma.ali@umt.edu.my
}

Accepted 4 October 2021, Published online 30 November 2021

\begin{abstract}
The main factors in reducing foodborne outbreaks are good knowledge, attitude, practice, and perception $\left(\mathrm{KAP}^{2}\right)$ of food poisoning prevention. Nevertheless, limited $\mathrm{KAP}^{2}$ studies have been conducted among consumers, particularly in rural areas. Thus, this preliminary study was conducted to evaluate the current level of food poisoning prevention $\mathrm{KAP}^{2}$ before intervention among 100 voluntary consumers in Kuala Nerus, Terengganu, selected through a non-probability convenience sampling. The KAP ${ }^{2}$ questionnaire was used and consists of five sections: socio-demographic, knowledge (42 items), attitude (10 items), practices (10 items), and perception (5 items). The scoring method used the original Bloom's cut-off points with good level: 80\%-100\%; moderate level: 60-79\%; and poor level: $\leq 59 \%$. Overall, the results showed a moderate knowledge's level with a median knowledge score of 29.0 (IQR 7.0) out of 42.0, a positive attitude with 46.0 (IQR 7.0) out of 50.0, good practice's level with 34.0 (IQR 5.0) out of 40.0, and a moderate perception's level on food poisoning prevention with 17.5 (IQR 4.0) out of 25.0. In conclusion, evaluating $\mathrm{KAP}^{2}$ before intervention is essential in developing an efficient educational program.
\end{abstract}

Keywords: knowledge, attitude, practice, perception, consumer, food poisoning prevention, rural area

\section{INTRODUCTION}

The issue of foodborne diseases has received considerable critical attention. It results from consuming contaminated foods and drinks with a wide range of causes, including radioactive substances, poisonous chemicals, infectious organisms (viruses and bacteria), and other harmful substances (Zyoud et al., 2019). Nausea, diarrhoea, vomiting, stomachache, fever, headache, and lethargy are common food poisoning symptoms (Ministry of Health Malaysia, 2019). The incidence

\footnotetext{
* To whom correspondence should be addressed
}

rate of food poisoning cases in Malaysia rose significantly from 17.76 in 2005 to 45.71 in 2018 per 100,000 population, with two deaths recorded due to food poisoning in 2015, six in 2016, and four in 2017 (Ministry of Health Malaysia, 2018), indicating a rise in cases of food poisoning-related mortality. Besides, Terengganu had the highest incidence rate of food poisoning in Malaysia, with 33.16 in 2018 and 68.9 incidents per 100,000 people in 2019 (Ministry of Health Malaysia, 2019). Food poisoning is becoming increasingly severe, especially among rural communities, due to a lack of public health awareness and prevention of food poisoning (Ministry of Health Malaysia, 2006; Bisholo et al., 
2018; Chellaiyan et al., 2018). As a result, more efforts are required to reduce food poisoning cases in Malaysia, especially in rural areas.

Previous research by Ruby et al. (2019a) and Salleh et al. (2017) has shown that most food poisoning in Malaysia have increased due to dining out. Mahmood et al. (2018) and Mohd. Firdaus et al. (2015) have also suggested that dining out triggers Malaysia's highest incidence. Besides, 97\% of food poisoning cases are caused by poor food handling and storage equipment, inadequate hygienic procedures, poor food handlers' hygiene, and unsanitary food premises (Todd et al., 2007; AbdulMutalib et al., 2015; Salleh et al., 2017). Most of these variables are linked to the food handlers directly. Previous surveys have found that food premise cleanliness and food handlers' hygiene are critical issues (Ungku Fatimah et al., 2011; Mohd. Firdaus et al., 2015). Most of the knowledge, attitude, practice and perception $\left(\mathrm{KAP}^{2}\right)$ study on food poisoning prevention has been conducted among food handlers (Zulkifly et al., 2013; Ismail et al., 2016; Woh et al., 2016; Dora-Liyana et al., 2018). Contrary to consumers, food handlers presumably have a better performance in the practice of food safety than consumers because of training for food handlers are supervised by authorities (Ministry of Health Malaysia, 2016; Ruby et al., 2019b). Ali et al. (2018) had reported that a lack of knowledge and preventive behaviour concerning food safety and hygiene might result in incidents of food poisoning and death among consumers since consumers in the food supply chain are the end-users.

While most previous research and literature focused on food handlers' awareness and intervention, the study filled the gap in understanding the $\mathrm{KAP}^{2}$ among consumers, especially in rural areas. Similarly, earlier studies showed limited consumers' $\mathrm{KAP}^{2}$ studies (Lim et al., 2015; Ruby et al., 2019b), and no formal food safety education programme in East Malaysia was exposed to consumers (Ruby et al., 2019b). Moreover, it is crucial to assess the perception of the prevention of food poisoning by understanding the motivating factors and influencing one's conduct in the prevention of diseases (Sukeri et al., 2020). Therefore, this current study has been conducted among consumers to avoid food poisoning prevention during dining out.

The evaluation of the baseline data is essential. Zyoud et al. (2019) had reported that baseline data are known as data before any intervention is given, which is an essential step to determine the relevant health education programme in preventing food poisoning during dining out. Therefore, the present study examined the consumer's degree of $\mathrm{KAP}^{2}$ of food poisoning prevention before intervention as a baseline assessment for an educational intervention programme to avoid food poisoning during dining out.

\section{MATERIALSAND METHODS}

The current study conducted a baseline assessment in Kuala Nerus, Terengganu in March 2020. The study in Kuala Nerus, Terengganu, was carried out because of concerns in increasing food poisoning as reported by the Ministry of Domestic Trade and Consumer Affairs in 2018 (Has et al., 2018). The villages in Kuala Nerus with less than 10,000 population were selected in the current study as the population density of less than 10,000 classified as a rural area in Terengganu due to low-density areas (Ministry of Rural Development, 2016).

Non-probability convenience sampling was used to select 100 respondents based on inclusion and exclusion criteria. The sample size was calculated using the formula suggested by Attri and Kaur (2016) and Charan and Biswas (2013). Taking a standard deviation (SD) of handwashing practice with 24.17 in the intervention group, the differences of the mean (d2) of practice score between intervention and control group with 14.30 , the power of 0.8 , Type 1 error of 0.05 , and the ration between intervention and control group of $1: 1$, resulting the minimum sample size needed in this study was 45 respondents per group (Nik Rosmawati et al., 2018). After 10\%, the final minimum sample size was 50 respondents per group. A total of 100 respondents were used as a total in this study.

The participants were inclusive of foods purchased outside at least once a week; ages 18 and over; readiness for 12 weeks of study; and the ability to read and write in Malay as a questionnaire was provided in the Malay language. Furthermore, the exclusion criteria for selecting the participants were refusal to participate, inability to consent from participants, and a halfway questionnaire. A onepage flyer was distributed to consumers, which describes the study's details and respondents' eligibility criteria. The selected consumers were invited to assemble in their villages' council hall. They were informed through the study's subject information sheet of aims and goals, and each participant signed written informed consent. After completing the questionnaire, each of the respondents received a token of appreciation. The study's ethical approval was obtained from the Ethics Committee of the Human Subjects Research of the Faculty of Medicine and Health Sciences of Universiti Putra Malaysia (UPM) (JKEUPM-2019302). 
The $\mathrm{KAP}^{2}$ was pre-tested, improved (Nur Afifah et al., 2020), and eventually used for this survey. The validated self-administered $\mathrm{KAP}^{2}$ questionnaire was adapted with modification from previous studies and consists of five sections: socio-demography, knowledge, attitude, practices, and perception. The scoring method used the initial cut-off points for Bloom with $80 \%-100 \%$ (good), 60\% -79\% (moderate), and $\leq 59 \%$ (poor), which were adapted and modified by Abdullahi et al. (2016) from the previous food safety KAP study.

Knowledge on food poisoning and its prevention included 42 questions consist of disease aetiology (4 items), high-risk foods (10 items), food poisoning signs and symptoms (10 items), food poisoning complication (5 items), food spoilage detection (3 items), and food poisoning prevention (10 items) (Low et al., 2015; Mahmood et al., 2018; Ruby et al., 2019b). A score of "1" is given for every correct answer while " 0 " is given for any incorrect, unsure, and unanswered question. The lowest score is 0 , and the maximum score is 42 . Thus, food poisoning knowledge was divided into three levels based on Bloom's cut-offs' range of percentages: good level: 34-42; moderate level: 25-33 scores; and poor level 0-24 scores.

The food poisoning prevention attitude includes ten questions assessing the general approach to food poisoning with cognitive domain behaviour (Nik Rosmawati et al., 2016; Zainuddin et al., 2018). A 5 point of Likert scale was used with " $1=$ strongly disagree", " $2=$ disagree", " $3=$ neither agree nor disagree", " $4=$ agree", and " $5=$ strongly agree". In the meantime, reverse scoring was used for the negative statement. The minimum score is 10 , while the maximum score is 50 . The results were divided into three levels by Bloom's cuts: 40-50 scores (positive), 30-39 scores (moderate), and 10-29 scores (negative).

The practice of food poisoning includes ten issues on the key area of prevention and risk reduction practices for food poisoning prevention (Low et al., 2016; Odeyemi et al., 2018; Zainuddin et al., 2018). The 4 points of the Likert scale was used with " $1=$ never", " 2 seldom", " $3=$ sometimes" and " $4=$ always". The reverse scoring was used for the negative statement. The minimum score is 10 , with a maximum score of 40. According to Bloom's cuts, the scores were classified into three levels: good: $32-40$ scores; moderate: 24-31 scores; and poor: 10-23 scores.

The perception of food poisoning prevention consisted of five questions that assessed barriers (3 items) and susceptibility (2 items) in two main domains (Hanson et al., 2015; Gupta et al., 2018). A 5 point of Likert scale was used with " $1=$ strongly disagree", " $2=$ disagree", " $3=$ neither agree nor disagree", " $4=$ agree", and " $5=$ strongly agree". The minimum score is 5 , while the maximum score is 25 . According to Bloom's cut-offs, the scores were divided into three levels: good: 20-25 scores; moderate: 15-19 scores; and poor: 5-14 scores.

The psychometric properties of the selfadministered $\mathrm{KAP}^{2}$ questionnaire were checked. The validity analysis on the knowledge section was conducted using difficulties and discrimination indexes (Nik Rosmawati et al., 2015). The difficulty index showed that out of 42 knowledge items, 28 items were too easy, 11 items were within an acceptable range, and three were difficult (Zaujan et al., 2021). The discrimination index for 42 items showed 25 items with low discrimination power, of which three items showed good discrimination, and 11 items exhibited excellent discrimination. Albuquerque et al. (2014); Squires et al. (2011); and Tapsir et al. (2018) had reported that inter-item correlation $(>0.30)$ and itemtotal correlation $(>0.30)$ used in construct validity. Therefore, the construct validity on attitude showed five items were deleted, followed by three practice items, and ten perception items.

The remaining items of attitude, practice, and perception were evaluated for reliability. To measure internal consistency, reliability tests were conducted using Cronbach's alpha. The results showed very good reliability in the attitude, and acceptable reliability in the practice and perception (Zaujan et al., 2021).

The data were presented as frequencies with percentages for nominal variables and mean \pm standard deviation (SD) or median and interquartile range (IQR) for numerical variables. The score of knowledge, attitude, practice, and perception was tested for normality using the Kolmogorov-Smirnov test. Since all scores' normality was not met, with a significance level of $5 \%$, the data was performed in a not-normally distributed median (IQR). The correlation analysis was conducted using Spearman's rank-order test.

\section{RESULTS}

\section{Socio-demographic data}

Table 1 shows the socio-demographic data of the respondents. The majority of respondents were female $(64.0 \%), 21-30$ years old $(27.0 \%)$, married $(70.0 \%)$, educational level of secondary school (48.0\%), and unemployed (46.0\%). More than half of the respondents $(51.0 \%)$ had an income level of less than RM500 due to unemployed persons.

\section{Knowledge on food poisoning and its prevention}

The knowledge level among consumers was moderate, with a median knowledge score of 29.0 (IQR 7.0). The response to each of the questions in the section of knowledge was presented in Table 2 . 
Table 1. Socio-demographic data of the respondents

\begin{tabular}{|c|c|c|}
\hline \multirow{2}{*}{ Socio-demographic characteristics } & \multicolumn{2}{|c|}{ Distribution } \\
\hline & $n$ & $\%$ \\
\hline \multicolumn{3}{|l|}{ Gender } \\
\hline Male & 36 & 36.0 \\
\hline Female & 64 & 64.0 \\
\hline \multicolumn{3}{|l|}{ Age group } \\
\hline 18-20 years & 9 & 9.0 \\
\hline $21-30$ years & 27 & 27.0 \\
\hline $31-40$ years & 19 & 19.0 \\
\hline $41-50$ years & 20 & 20.0 \\
\hline$>50$ years & 25 & 25.0 \\
\hline \multicolumn{3}{|l|}{ Ethnic } \\
\hline Malay & 100 & 100.0 \\
\hline \multicolumn{3}{|l|}{ Marital status } \\
\hline Single & 25 & 25.0 \\
\hline Married & 70 & 70.0 \\
\hline Separated/Divorced/Widowed & 5 & 5.0 \\
\hline \multicolumn{3}{|l|}{ Academic qualification } \\
\hline Informal education & 1 & 1.0 \\
\hline Primary school & 4 & 4.0 \\
\hline Secondary school & 48 & 48.0 \\
\hline Certificate/STPM/A level/GCE/Foundation/Matriculation/Diploma & 30 & 30.0 \\
\hline Tertiary Education (Degree/Master/Phd) & 17 & 17.0 \\
\hline \multicolumn{3}{|l|}{ Job sector } \\
\hline Self-employed & 22 & 22.0 \\
\hline Government sector & 12 & 12.0 \\
\hline Private sector & 20 & 20.0 \\
\hline Unemployed & 46 & 46.0 \\
\hline \multicolumn{3}{|l|}{ Monthly individual income } \\
\hline RM 0 - RM 500 & 51 & 51.0 \\
\hline RM 501 - RM 1000 & 17 & 17.0 \\
\hline RM 1001 - RM 1500 & 15 & 15.0 \\
\hline RM 1501 - RM 2000 & 5 & 5.0 \\
\hline$>$ RM 2000 & 12 & 12.0 \\
\hline
\end{tabular}

Most of the respondents agreed that bacteria (96.0\%), viruses $(51.0 \%)$, and pesticides $(67.0 \%)$ are food poisoning causative agents, compared to parasites (45.0\%). When asked about high-risk foods, $79.0 \%$ of respondents correctly answered on poultry followed by meat $(66.0 \%)$, bread $(57.0 \%)$, dairy products $(77.0 \%)$, and seafood $(65.0 \%)$. However, $59.0 \%$ of respondents incorrectly answered on vegetables and $67.0 \%$ on fruits. Concerning food poisoning signs and symptoms, the majority of respondents responded correctly to diarrhoea (97.0\%), vomiting (95.0\%), abdominal pain $(94.0 \%)$, lethargy $(83.0 \%)$, and fever $(54.0 \%)$. Meanwhile, only $17.0 \%$ of respondents responded correctly to yellow eyes (jaundice), $36.0 \%$ to bloody stools, and $44.0 \%$ to muscle pain as signs and symptoms of food poisoning. Besides, most respondents responded correctly to the knowledge of food poisoning complications of death $(67.0 \%)$ and dehydration (70.0\%), while only $20.0 \%$ responded correctly to kidney failure and $18.0 \%$ to liver failure. Surprisingly, the majority of respondents agreed that a physical change in food $(92.0 \%)$, a foul smell of food $(93.0 \%)$, and a change in food taste $(94.0 \%)$ are signs of spoilage in food. Also, respondents recognize the prevention of food poisoning. The respondents agreed that food should be thoroughly cooked $(93.0 \%)$, and eggs washed before cooking (92.0\%). Also, they agreed to wash hands with soap after using the toilet $(92.0 \%)$, separate raw food from cooked food $(88.0 \%)$, avoid pests in food premises $(94.0 \%)$, and practice good personal hygiene $(94.0 \%)$. The results show a moderate level of knowledge among the respondents.

\section{Attitude on food poisoning prevention}

The respondents' level of attitude was positive, with a median knowledge score of 46.0 (IQR 7.0). The response in the section on food poisoning preventive attitude during dining out was presented in Table 3. The majority of respondents agreed that they were aware of food handlers smoking behaviour 
Table 2. Knowledge towards food poisoning and its prevention

\begin{tabular}{|c|c|c|}
\hline Statements & $\begin{array}{c}\text { Correct } \\
n(\%)\end{array}$ & $\begin{array}{l}\text { Incorrect/Unsure } \\
n(\%)\end{array}$ \\
\hline \multicolumn{3}{|l|}{ Knowledge of disease aetiology } \\
\hline $\mathrm{K} 1 \mathrm{a}$ Cause of food poisoning is bacteria & $96(96.0)$ & $4(4.0)$ \\
\hline $\mathrm{K} 1 \mathrm{~b}$ Cause of food poisoning is the virus & $51(51.0)$ & $49(49.0)$ \\
\hline $\mathrm{K} 1 \mathrm{c}$ Cause of food poisoning is a parasite & $45(45.0)$ & $55(55.0)$ \\
\hline K1d Cause of food poisoning is pesticide residue & $67(67.0)$ & $33(33.0)$ \\
\hline \multicolumn{3}{|l|}{ Knowledge of high-risk foods } \\
\hline $\mathrm{K} 2 \mathrm{a}$ High-risk food is poultry & $79(79.0)$ & $21(21.0)$ \\
\hline $\mathrm{K} 2 \mathrm{~b}$ High-risk food is meat & $66(66.0)$ & $34(34.0)$ \\
\hline K2c High-risk food is bread & $57(57.0)$ & $43(43.0)$ \\
\hline $\mathrm{K} 2 \mathrm{~d}$ High-risk food is dried foods & $45(45.0)$ & $55(55.0)$ \\
\hline K2e High-risk food is dairy products & $77(77.0)$ & $23(23.0)$ \\
\hline $\mathrm{K} 2 \mathrm{f}$ High-risk food is seafood & $65(65.0)$ & $35(35.0)$ \\
\hline $\mathrm{K} 2 \mathrm{~g} \mathrm{High-risk} \mathrm{food} \mathrm{is} \mathrm{rice}$ & $49(49.0)$ & $54(54.0)$ \\
\hline $\mathrm{K} 2 \mathrm{~h}$ High-risk food is canned food whilst unopened or indented & $29(29.0)$ & $71(71.0)$ \\
\hline $\mathrm{K} 2 \mathrm{i}$ High-risk food is vegetables & $41(41.0)$ & $59(59.0)$ \\
\hline K2j High-risk food is fruits & $33(33.0)$ & $67(67.0)$ \\
\hline \multicolumn{3}{|l|}{ Food poisoning signs and symptoms } \\
\hline K3a Diarrhoea & $97(97.0)$ & $3(3.0)$ \\
\hline K3b Vomiting & $95(95.0)$ & $5(5.0)$ \\
\hline K3c Abdominal pain & $94(94.0)$ & $6(6.0)$ \\
\hline K3d Dryness of lips & $43(43.0)$ & $57(57.0)$ \\
\hline K3e Lethargy & $83(83.0)$ & $17(17.0)$ \\
\hline K3f Yellow eyes (jaundice) & $17(17.0)$ & $83(83.0)$ \\
\hline K3g Fever & $54(54.0)$ & $46(46.0)$ \\
\hline K3h Bloody stool & $36(36.0)$ & $64(64.0)$ \\
\hline K3i Muscle pain & $44(44.0)$ & $56(56.0)$ \\
\hline K2j Gum bleeding & $56(56.0)$ & $44(44.0)$ \\
\hline \multicolumn{3}{|l|}{ Food poisoning complication } \\
\hline K4a Death & $67(67.0)$ & $33(33.0)$ \\
\hline K4b Kidney failure & $20(20.0)$ & $80(80.0)$ \\
\hline K4c Liver failure & $18(18.0)$ & $82(82.0)$ \\
\hline K4d Dehydration & $70(70.0)$ & $30(30.0)$ \\
\hline K4e Respiratory failure & $18(18.0)$ & $82(82.0)$ \\
\hline \multicolumn{3}{|l|}{ Spoil food detection } \\
\hline K5a Physical change of food & $92(92.0)$ & $8(8.0)$ \\
\hline K5b Food smells foul & $93(93.0)$ & $7(7.0)$ \\
\hline $\mathrm{K} 5 \mathrm{c}$ Change of the food taste & $94(94.0)$ & $6(6.0)$ \\
\hline \multicolumn{3}{|l|}{ Food poisoning prevention } \\
\hline K6a Ensure the food is thoroughly cooked & $93(93.0)$ & $7(7.0)$ \\
\hline K6b Using the same cloth to wipe countertop and plates & $80(80.0)$ & $20(20.0)$ \\
\hline K6c Using the same chopping board to cut different raw foods & $66(66.0)$ & $34(34.0)$ \\
\hline K6d Washing eggs before cooking & $92(92.0)$ & $8(8.0)$ \\
\hline K6e Washing hands using soaps each time after using a toilet & $92(92.0)$ & $8(8.0)$ \\
\hline K6f Washing hand using liquid soap & $88(88.0)$ & $12(12.0)$ \\
\hline $\mathrm{K} 6 \mathrm{~g}$ Eating cooked food that is kept at room temperature for $12-24$ hours & $59(59.0)$ & $41(41.0)$ \\
\hline K6h Raw food should be kept separate from cooked food & $88(88.0)$ & $12(12.0)$ \\
\hline $\begin{array}{l}\text { K6i Avoid pests such as rodents, cockroaches, and flies' harbourage in } \\
\text { the food premises }\end{array}$ & $94(94.0)$ & $6(6.0)$ \\
\hline K6j Practice a good personal hygiene & $94(94.0)$ & $6(6.0)$ \\
\hline
\end{tabular}

while preparing or handling food (72.0\%). Concerning the attitude of choosing the food premises, the respondents choose food premise with food handlers wear gloves during food preparation $(88.0 \%)$, reject food premise with food handlers' nails are not trimmed $(84.0 \%)$, aware on food premise hygiene in choosing food premise prior dine out $(87.0 \%)$, and ensure food premise they visit clean $(95.0 \%)$. The results showed that the respondents were aware of the food premises' cleanliness and the food handlers' hygiene before dining out. Next, there was a significant percentage of reactions to the report to the authorities. Surprisingly, the majority of respondents will complain to authorities if they 
Table 3. Attitude towards food poisoning prevention

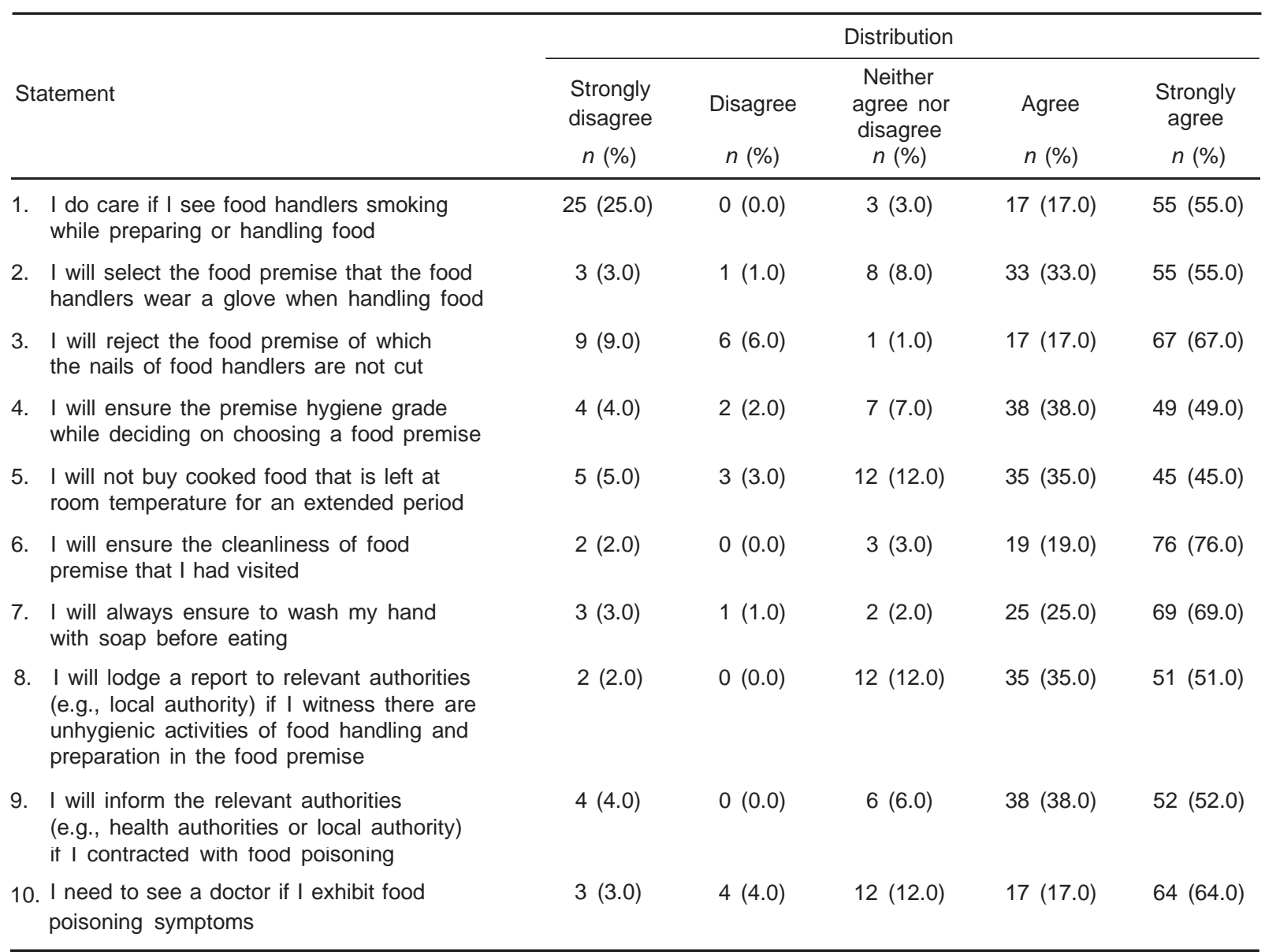

witness unhygienic food preparation in food premises $(86.0 \%)$ and if they are contracted with food poisoning $(90.0 \%)$. The results show that most respondents are aware of their rights as consumers. The overall response to the attitude section was very positive.

\section{Practice on food poisoning prevention}

The level of practice among respondents was good, with a median practice score of 34.0 (IQR 5.0). Table 4 presents the response to food poisoning prevention practices during dining out. A high percentage of respondents agreed that they would wash their hands before they ate $(98.0 \%)$ and use liquid soap over the bar when they wash their hands (97.0\%). When asked about behaviour at the food premises, the respondents agreed to seek cleanliness before entering food premise (87.0\%); and reject food premises with food handlers smoke during food preparation $(89.0 \%)$, do not wear an apron $(82.0 \%)$, gloves $(79.0 \%)$, and headcover $(81.0 \%)$ during food preparation. The results showed they had a good practice in choosing clean food premises with hygienic food handlers. Next, surprisingly, $93.0 \%$ of respondents smell food to avoid eating spoiled food.
The result shows that they were aware of food poisoning prevention by smelling the food before it was consumed. However, only $52.0 \%$ of respondents do not spit around the food premises.

\section{Perception on food poisoning prevention}

The respondents' level of perception was moderate, with a median score of 17.0 (IQR 4.0). The response in the perception section was presented in Table 5. For perceived barriers to food poisoning preventive behaviour, only $47.0 \%$ agreed it is time-consuming to choose clean food premises and $23.0 \%$ feel that treatment in the hospital due to food poisoning is inconvenient. However, the respondents showed high perceived barriers to preventing food poisoning during dining out, with $64.0 \%$ believe that a high level of effort is needed to ensure the food premises' cleanliness. Next, most of the respondents agreed that the foods $(91.0 \%)$ and drinks $(94.0 \%)$ consumed daily were safe.

Relationship between knowledge, attitude, and practice towards food poisoning prevention

A significant positive relationship was found between knowledge, attitude, and practice on food 
Table 4. Practice towards food poisoning prevention

\begin{tabular}{|c|c|c|c|c|}
\hline \multirow{2}{*}{ Statements } & \multicolumn{4}{|c|}{ Distribution } \\
\hline & $\begin{array}{l}\text { Never } \\
n(\%)\end{array}$ & $\begin{array}{l}\text { Seldom } \\
n(\%)\end{array}$ & $\begin{array}{c}\text { Sometimes } \\
n(\%)\end{array}$ & $\begin{array}{c}\text { Always } \\
n(\%)\end{array}$ \\
\hline 1. I wash my hand clean before eating & $0(0.0)$ & $2(2.0)$ & $8(8.0)$ & $90(90.0)$ \\
\hline 2. I will use liquid soap over the bar when washing my hands & $0(0.0)$ & $3(3.0)$ & $26(26.0)$ & $71(71.0)$ \\
\hline 3. I do not spit around the food premise & $44(44.0)$ & $2(2.0)$ & $2(2.0)$ & $52(52.0)$ \\
\hline $\begin{array}{l}\text { 4. I reject food premises of which the food handlers are } \\
\text { smoking during food handling }\end{array}$ & $2(2.0)$ & $9(9.0)$ & $24(24.0)$ & $65(65.0)$ \\
\hline $\begin{array}{l}\text { 5. I look for the cleanliness grade before entering the } \\
\text { food premises }\end{array}$ & $2(2.0)$ & $11(11.0)$ & $33(33.0)$ & $54(54.0)$ \\
\hline 6. I will see the doctor if I exhibit food poisoning symptoms & $7(7.0)$ & $9(9.0)$ & $14(14.0)$ & $70(70.0)$ \\
\hline $\begin{array}{l}\text { 7. I reject the food premises of which the food handlers } \\
\text { do not wear an apron while handling food }\end{array}$ & $4(4.0)$ & $14(14.0)$ & $47(47.0)$ & $35(35.0)$ \\
\hline $\begin{array}{l}\text { 8. I reject the food premises of which the food handlers } \\
\text { do not wear a glove while handling food }\end{array}$ & $11(11.0)$ & $10(10.0)$ & $47(47.0)$ & $32(32.0)$ \\
\hline $\begin{array}{l}\text { 9. I reject food premises on which the food handlers } \\
\text { do not wear headcover }\end{array}$ & $8(8.0)$ & $11(11.0)$ & $36(36.0)$ & $45(45.0)$ \\
\hline 10. I will smell the food to ensure the food is not spoilt & $3(3.0)$ & $4(4.0)$ & $41(41.0)$ & $52(52.0)$ \\
\hline
\end{tabular}

Table 5. Perception towards food poisoning prevention

\begin{tabular}{|c|c|c|c|c|c|}
\hline \multirow[b]{2}{*}{ Statements } & \multicolumn{5}{|c|}{ Distribution } \\
\hline & $\begin{array}{c}\text { Strongly } \\
\text { disagree } \\
n(\%)\end{array}$ & $\begin{array}{c}\text { Disagree } \\
n(\%)\end{array}$ & $\begin{array}{c}\text { Neither } \\
\text { agree nor } \\
\text { disagree } \\
n(\%)\end{array}$ & $\begin{array}{l}\text { Agree } \\
n(\%)\end{array}$ & $\begin{array}{c}\text { Strongly } \\
\text { agree } \\
n(\%)\end{array}$ \\
\hline \multicolumn{6}{|l|}{ Perceived barriers } \\
\hline $\begin{array}{l}\text { 1. I think that it is time-consuming to } \\
\text { choose a clean food premise }\end{array}$ & $2(2.0)$ & $27(27.0)$ & $24(24.0)$ & $34(34.0)$ & $13(13.0)$ \\
\hline $\begin{array}{l}\text { 2. I feel that getting treatment in the hospital } \\
\text { or clinic due to food poisoning is inconvenient }\end{array}$ & $14(14.0)$ & $55(55.0)$ & $8(8.0)$ & $16(16.0)$ & $7(7.0)$ \\
\hline $\begin{array}{l}\text { 3. I believe that ensuring the cleanliness of } \\
\text { food premises requires high effort }\end{array}$ & $4(4.0)$ & $12(12.0)$ & $23(23.0)$ & $46(46.0)$ & $15(15.0)$ \\
\hline \multicolumn{6}{|l|}{ Perceived susceptibility } \\
\hline $\begin{array}{l}\text { 4. I think foods that I take daily are safe to } \\
\text { be consumed }\end{array}$ & $1(1.0)$ & $2(2.0)$ & $6(6.0)$ & $52(52.0)$ & $39(39.0)$ \\
\hline $\begin{array}{l}\text { 5. I think the drinks that I take daily are safe } \\
\text { to be consumed }\end{array}$ & $1(1.0)$ & $1(1.0)$ & $4(4.0)$ & $50(50.0)$ & $44(44.0)$ \\
\hline
\end{tabular}

poisoning prevention during dining out (Table 6). There was a significant weak relationship between knowledge and attitude ( $r h o=0.271, p=0.006)$, and a moderate relationship between knowledge and practice $(r h o=0.444, p=0.000$ ). The attitude on food poisoning prevention had a weak relationship towards knowledge $(r h o=0.271, p=0.006)$ and practice ( $r h o=0.372, p=0.000)$. Besides, there was a moderate relationship between practice and knowledge ( $r h o=0.444, p=0.000$ ), and a weak relationship between practice and attitude ( $r h o=0.372, p=0.000)$.

\section{DISCUSSION}

Overall, the results showed a moderate level of knowledge, a positive attitude, good practice, and a moderate perception level. Food poisoning may be caused by a wide range of aetiological agents known as causative agents, including bacteria, viruses, fungi, parasites, and even prions (Rodriguez-Morales et al., 2016). Among the knowledge items assessed in this study, consumers' understanding of the parasite as a causative agent was poor based on their 
Table 6. Relationship between knowledge, attitude, and practice towards food poisoning and its prevention

\begin{tabular}{|c|c|c|c|c|}
\hline Variables & Spearman's rho & Knowledge & Attitude & Practice \\
\hline Knowledge & $\begin{array}{c}\text { Correlation coefficient } \\
p \text {-value }\end{array}$ & 1.000 & $\begin{array}{l}0.271 \\
0.006^{*}\end{array}$ & $\begin{array}{l}0.444 \\
0.000^{*}\end{array}$ \\
\hline Attitude & $\begin{array}{c}\text { Correlation coefficient } \\
p \text {-value }\end{array}$ & $\begin{array}{l}0.271 \\
0.006^{*}\end{array}$ & 1.000 & $\begin{array}{l}0.372 \\
0.000^{*}\end{array}$ \\
\hline Practice & $\begin{array}{l}\text { Correlation coefficient } \\
p \text {-value }\end{array}$ & $\begin{array}{l}0.444 \\
0.000^{*}\end{array}$ & $\begin{array}{l}0.372 \\
0.000^{*}\end{array}$ & 1.000 \\
\hline
\end{tabular}

${ }^{*}$ Correlation is statistically significant at $p<0.05$.

lowest percentage of correct responses. A minimum percentage of knowledge on the causative agent of food poisoning was also identified in the previous study by Ali et al. (2018) which conducted a KAP study on food safety and hygiene among university students in Kedah, Malaysia. Similarities between the findings have shown that consumers still do not know and pay little attention to the dangers of being contaminated with parasites that could cause outbreaks of food poisoning. It agrees with earlier studies that parasites' transmission could cause food contamination resulting from food poisoning (Ngoc et al., 2011; Sharifa Ezat et al., 2013; Ruby et al., 2019a). Preventive strategies to prevent parasites from being contaminated, including good hygiene practices such as hand washing, and washing vegetables and fruit before they are consumed (Rodriguez-Morales et al., 2016). To protect consumers from food poisoning, consumers must be aware of the cleanliness of food preparation areas and food hygiene, also practice good food poisoning prevention behaviour.

The present study showed that consumers had high knowledge of the signs and symptoms of food poisoning. This finding is similar to previous research by Ferk et al. (2016), in which the majority of consumers were able to recognize the symptoms of food poisoning correctly. To avoid food poisoning, consumers must recognize the signs of food poisoning so that they can receive appropriate medical treatment before the symptoms worsen and lead to death. Furthermore, when it comes to customer awareness of food poisoning avoidance, the present survey found that most people understand cross-contamination because they use different towels to clean tables and plates and different chopping boards to cut other raw foods. To avoid cross-contamination, a previous study Saipullizan et al. (2018) conducted in the rural area of Kuala Pilah, Malaysia, reported that different clothes must be used to clean tables and food utensils, as well as different chopping boards.
Another important finding in the current study was that consumers had achieved an adequate understanding of high-risk foods. However, consumers had poor knowledge of high-risk foods for rice, vegetables, and fruit. The finding was similar to the previous study by Ruby et al. (2019a) and reported that consumers with less knowledge of high-risk foods would consume raw food which is a potential medium for the growth of foodborne pathogens. Australian Institute of Food Safety (2020) has stated that rice, fruit, and vegetables are highrisk food. Bacillus cereus grows as spores in uncooked rice causing food intoxication, also known as fried rice syndrome (Mohammad Nazrul, 2019). Next, vegetables and fruit can act as a vehicle for bacteria to grow cause food poisoning (Australian Institute of Food Safety, 2020). This statement was supported by Nesbitt et al. (2009) that washing fresh fruit and vegetables is the most successful way to reduce consumers' risk of infection. The results indicate that public health messages focusing on the importance of washing fruit and vegetables towards consumers are needed.

Despite having a moderate level of knowledge, positive attitude, and good practice, the number of respondents spitting around is considered high, indicating a poor attitude. Spitting in public areas, including food premises, can contribute to the spread of infections and contagious diseases. Certain diseases can spread from one person to another in droplets of saliva (Serena, 2020). Therefore, educational programs in improving consumer's attitudes and practices are necessary to prevent food poisoning, particularly during dining out.

The current study found a significantly positive relationship between knowledge, attitude, and practice towards food poisoning and its prevention. It is aligned with the several studies which reported that the level of knowledge influences the positive attitude and practice (Mohd. Firdaus et al., 2015; Norhaslinda et al., 2016; Ali et al., 2018). Besides, a study by Cheng et al. (2017) found that positive 
practice stems from a positive attitude derived from an adequate knowledge of food safety. These results showed that as knowledge of food poisoning increases, preventive behaviour and practice would improve accordingly. However, these findings are contrary to a previous study by Abdullahi et al. (2016), which reported no significant correlation between knowledge, attitude, and practice on food safety. According to the previous research knowledge often does not contribute to developing positive attitudes and actions (Redmond \& Griffith, 2003; Zyoud et al., 2019). Nevertheless, it still can be concluded that a high level of food safety knowledge can contribute to the positive attitude and practices towards food poisoning preventive behaviour.

The inconsistency of the results may be due to the perception that influences consumers' preventive behaviour during dining out. The view was supported by a previous study by Ab Rahman et al. (2018), which noted that KAP was influenced by how people perceived susceptibility and barriers to preventive practice. Perceived susceptibility defines people who believe they are exposed to the disease; and perceived barriers as obstacles to the practice of preventive behaviour, such as high costs and time spent acting (Ab Rahman et al., 2018). It can be assumed that a high level of consumers' knowledge of food poisoning does not guarantee a positive attitude and practice of food poisoning due to these factors. Therefore, besides improving knowledge, attitude, and practice, future educational studies on improving consumer perceptions are also essential to prevent food poisoning, particularly during dining out.

\section{CONCLUSION}

The current study showed there were a positive attitude and practice on food poisoning prevention. However, there was only a moderate level of knowledge and perception, which might influence the preventive food poisoning behaviour. In conclusion, these findings suggest that an educational programme is one of the initiatives that can be taken to increase consumers' knowledge, attitudes, practices, and perceptions of food poisoning prevention during dining out.

\section{ACKNOWLEDGEMENT}

This study was supported by the Malaysia Research University Network (MRUN) UPM grant: UPM/8004/11/MRUN/2018/5539240.

\section{REFERENCES}

Ab Rahman, M.H.A., Hairon, S.M., Hamat, R.A., Jamaluddin, T.Z.M.T., Shafei, M.N., Idris, N. \& Daud, A. 2018. Leptospirosis health intervention module effect on knowledge, attitude, belief, and practice among wet market workers in northeastern Malaysia: An intervention study. International Journal of Environmental Research and Public Health, 15(7): 1-12.

Abdul-Mutalib, N.A., Syafinaz, A.N., Sakai, K. \& Shirai, Y. 2015. An overview of foodborne illness and food safety in Malaysia. International Food Research Journal, 22(3): 896-901.

Abdullahi, A., Hassan, A., Kadarman, N., Saleh, A., Baraya, Y.S. \& Lua, P.L. 2016. Food safety knowledge, attitude, and practice toward compliance with abattoir laws among the abattoir workers in Malaysia. International Journal of General Medicine, 9: 79-87.

Albuquerque, C., Franco, V., Castro, F. \& Oliveira, C. 2014. Cross-cultural adaptation and validation of the Portuguese version of the "European Health and Behaviour Survey-section B". Atencion Primaria, 46(S5): 112-117.

Ali, A.N., William, A.F., Prajapati, S.K. \& Ahmed, N.Z. 2018. A KAP study on food safety and hygiene among private university students in Kedah State, Malaysia. Journal of Natural Remedies, 18(3): 114-121.

Attri, J.P. \& Kaur, H. 2016. Basic concepts for sample size calculation: Critical step for any clinical trials. Saudi Journal of Anaesthesia, 10(3): 65-68.

Australian Institute of Food Safety. 2020. 10 highrisk foods are more likely to cause food poisoning. URL https://www.foodsafety.com.au/ blog/10-high-risk-foods-more-likely-to-causefood-poisoning (accessed on 1 October 2020).

Becky, J.B. 2013. Using the health belief model to determine differences in university foodservice employees' beliefs and perceptions about handwashing and foodborne illness. Kansas State University (Master's Thesis).

Bisholo, K.Z., Ghuman, S. \& Haffejee, F. 2018. Foodborne disease prevalence in rural villages in the Eastern Cape, South Africa. African Journal of Primary Health Care \& Family Medicine, 10(1): 1-5.

Charan, J. \& Biswas, T. 2013. How to calculate sample size for different study designs in medical research. Indian Journal of Psychological Medicine, 35: 121-126.

Chellaiyan, V.G.J., Fasna, L.L. \& Mallika, S.V. 2018. Food safety awareness and food handling practices among the rural population of Tamil Nadu. International Journal of Community Medicine and Public Health, 5(4): 1441-1447. 
Cheng, Y., Zhang, Y., Ma, J. \& Zhan, S. 2017. Food safety knowledge, attitude and self-reported practice of secondary school students in Beijing, China: A cross-sectional study. PLoS One, 12(11): 1-13.

Dora-Liyana, A.L., Mahyudin, N.A., Ismail-Fitry, M.R., Ahmad-Zaki, A. \& Rasiyuddin, H. 2018. Food safety and hygiene knowledge, attitude and practices among food handlers at boarding schools in the northern region of Malaysia. International Journal of Academic Research in Business and Social Sciences, 8(17): 238-266.

Ferk, C.C., Calder, B.L. \& Camire, M.E. 2016. assessing the food safety knowledge of University of Maine Students. Journal of Food Science Education, 15(1): 14-22.

Gupta, V., Khanna, K. \& Gupta, R.K. 2018. A study on the street food dimensions and its effects on consumer attitude and behavioural intentions. Tourism Review, 73(3): 374-388.

Hanson, J.A., Hughes, S.M. \& Liu, P. 2015. Use of health belief model variables to examine selfreported food handling behaviours in a sample of U.S. adults attending a tailgate event. Journal of Food Protection, 78(12): 2177-2183.

Has, S.M.C., Jaafar, S.N.A. \& Chilek, T.Z.T. 2018. An assessment on pre-and post-food hygiene training on food safety's KAP level among food handlers in Kuala Terengganu and Kuala Nerus. Malaysian Applied Biology, 47(4): 61-69.

Ismail, F.H., Chik, C.T., Muhammad, R. \& Yusoff, N.M. 2016. Food safety knowledge and personal hygiene practices amongst mobile food handlers in Shah Alam, Selangor. Procedia - Social and Behavioral Sciences, 222: 290-298.

Lim, T., Yee, F., Rosni, M. \& Mohd, N. 2015. Structural modelling on food safety knowledge, attitude, and behaviour among Bum Bum Island community of Semporna, Sabah. Food Control, 60(2016): 241-246.

Low, W.Y., Jani, R., Halim, H.A., Alias, A.A. \& Moy, F.M. 2016. Determinants of food hygiene knowledge among youths: A cross-sectional online study. Food Control, 59(2016): 88-93.

Mahmood, K., Khalid, J., Kamilah, H., Janee Ali, A., Muhammad, L. \& Ariffin, F. 2018. An empirical study of food safety, food handling, and food poisoning awareness among foreign students in Penang, Malaysia. International Journal on Advanced Science Engineering Information Technology, 8(1): 150-156.

Ministry of Health Malaysia. 2019. Food poisoning - Portal MyHealth. URL http://www.myhealth. gov.my/en/food-poisoning/ (accessed 07.26. 2020).
Ministry of Health Malaysia. 2018. Health Facts, 2018. Ministry of Health Malaysia, Planning Division Health Informatics Centre, Selangor, Malaysia. pp. 1-19

Ministry of Health Malaysia. 2006. Malaysia's Health. Ministry of Health Malaysia, Information and Documentation System Unit, Selangor, Malaysia. pp. 83-85.

Ministry of Health Malaysia. 2016. Annual Report Food Safety and Quality Division. Ministry of Health Malaysia, Food Safety and Quality Department, Selangor, Malaysia. pp. 1-37.

Ministry of Health Malaysia. 2019. Foodborne statistics MOH 2004-2019. Ministry of Health Malaysia Disease Control Division, Selangor, Malaysia. pp. 1-10.

Ministry of Rural Development. 2016. Rural Development Policy. Ministry of Rural Development, Federal Government Administrative Centre, Putrajaya, Malaysia. pp. 1-11.

Mohammad Nazrul, I. 2019. Fried rice syndrome, a disease of the fast world: Scientific analysis. American Journal of Biomedical Science \& Research, 5(6): 512-514.

Mohd. Firdaus, S.A., Son, R., Mohhiddin, O., Toh, P.S. \& Chai, L.C. 2015. Food court hygiene assessment and food safety knowledge, attitudes and practices of food handlers in Putrajaya. International Food Research Journal, 22(5): 1843-1854.

Nesbitt, A., Majowicz, S., Finley, R., Marshall, B., Pollari, F., Sargeant, J.A.N. \& Sittler, N. 2009. High-risk food consumption and food safety practices in a Canadian community. Journal of Food Protection, 72(12): 2575-2586.

Ngoc, T., Thanh, C., Reviewers, P., Iwu, A.C., Uwakwe, K.A., Duru, C.B. \& Kosatsky, T. 2011. Assessing the knowledge, attitudes and practices of street food vendors in the city of Johannesburg regarding food hygiene and safety. Food Control, 30(May): 150-156.

Nik Rosmawati, N.H., Wan Muda, W.M., Noor Izani, N.J., Nik Nurain, N.H. \& Razlina, A.R. 2018. The effect of Food Safety Education on handwashing practices in school canteens' food handlers. Sains Malaysiana, 47(9): 2119-2128.

Nik Rosmawati, N.H., Wan Muda, W.M., Noor Izani, N.J. \& Nik Nurain, N.H. 2015. Validity and reliability of food safety knowledge and practices questionnaire among food handlers. Health and the Environment Journal, 6(1): 11-30. 
Nik Rosmawati, N.H., Wan Muda, W.M., Noor Izani, N.J., Nik Nurain, N.H. \& Razlina, A.R. 2016. Effect of food safety training on food handlers' knowledge and practices: A randomized controlled trial. British Food Journal, 118(4): 795-808.

Norhaslinda, R., Norhayati, A. \& Mohd Adzim, K.R. 2016. Knowledge, attitudes and practices (KAP) on good manufacturing practices (GMP) among food handlers in Terengganu hospitals. International Journal of Pharmacy and Pharmaceutical Sciences, 8(11): 53-59.

Nur Afifah, M.Z., Asma', A. \& Malina, O. 2020. Knowledge, attitude and practice regarding food poisoning and its prevention in Malaysia: A systematic literature review. Food Research, 4(6): 1832-1849.

Odeyemi, O.A., Sani, N.A., Obadina, A.O., Saba, C.K.S., Bamidele, F.A., Abughoush, M. \& Aberoumand, A. 2018. Food safety knowledge, attitudes and practices among consumers in developing countries: An international survey. Food Research International, 116: 1386-1390.

Redmond, E.C. \& Griffith, C.J. 2003. Consumer food handling in the home: A review of food safety studies. Journal of Food Protection, 66(1): 130161.

Rodriguez-Morales, A.J., Bolívar-Mejía, A., AlarcónOlave, C. \& Calvo-Betancourt, L.S. 2016. Parasites in food: Illness and treatment. encyclopedia of food and health. 1st Ed. Elsevier Ltd., Technological University of Pereira, Columbia. pp. 213-217.

Ruby, G.E., Fatimah, U., Zainal, U., Lihan, S., Noorahya, N. \& Radu, S. 2019a. A crosssectional study on food safety knowledge among adult consumers. Food Control, 99(2019): 98-105.

Ruby, G.E., Ungku Zainal Abidin, U.F., Lihan, S., Jambari, N.N. \& Radu, S. 2019b. Self-reported food safety practices among adult consumers in Sibu, Malaysia: A cross-sectional study. Food Protection Trends, 39(5): 366-376.

Saipullizan, S.N.A., Mutalib, S.A. \& Sedek, R. 2018. Knowledge, attitude and practice of food utensils hygiene amongst food handlers in Kuala Pilah, Negeri Sembilan, Malaysia. Sains Malaysiana, 47(7): 1527-1533.

Salleh, W., Lani, M.N., Abdullah, W.Z.W., Chilek, T.Z.T. \& Hassan, Z. 2017. A review on incidences of foodborne diseases and interventions for a better national food safety system in Malaysia. Malaysian Applied Biology, 46(3): $1-7$.
Serena, J.M. 2020. Spitting in public places too can spread infections. URL https://www.thehindu. com/news/cities/chennai/watch-out-spitting-inpublic-places-too-can-spread-infections/ article30814578.ece (accessed 10.04.2020).

Sharifa Ezat, W.P., Netty, D. \& Sangaran, G. 2013. Paper review of factors, surveillance, and burden of foodborne disease outbreak in Malaysia. Malaysian Journal of Public Health Medicine, 13(2): 1-7.

Squires, J.E., Estabrooks, C.A., Newburn-Cook, C.V. \& Gierl, M. 2011. Validation of the conceptual research utilization scale: An application of the standards for educational and psychological testing in healthcare. BMC Health Services Research, 11(1): 1-14.

Sukeri, S., Zahiruddin, W.M., Shafei, M.N., Hamat, R.A., Osman, M., Jamaluddin, T.Z.M.T. \& Daud, A.B. 2020. Perceived severity and susceptibility towards leptospirosis infection in Malaysia. International Journal of Environmental Research and Public Health, 17(17): 1-10.

Tapsir, R., Nik Pa, N.A. \& Zamri, S.N.A.B.S. 2018. Reliability and validity of the instrument measuring values in mathematics classrooms. Malaysian Online Journal of Educational Sciences, 6(2): 37-47.

Todd, E.C.D., Greig, J.D., Bartleson, C.A. \& Michaels, B.S. 2007. Outbreaks where food workers have been implicated in the spread of foodborne disease. Journal of Food Protection, 70: 21992217.

Ungku Fatimah, U.Z.A., Boo, H.C., Sambasivan, M. \& Salleh, R. 2011. Foodservice hygiene factors - The consumer perspective. International Journal of Hospitality Management, 30(1): 3845.

Woh, P.Y., Thong, K.L., Behnke, J.M., Lewis, J.W. \& Mohd Zain, S.N. 2016. Evaluation of basic knowledge on food safety and food handling practices amongst migrant food handlers in Peninsular Malaysia. Food Control, 70: 64-73.

Zainuddin, W.M., Ariffin, W.N., Mohd-Nazri, S., Sukeri, S., Zawaha, I., Bakar, R.A. \& Aziah, D. 2018. Development and validation of new knowledge, attitude, belief and practise questionnaire on leptospirosis in Malaysia. BMC Public Health, 18(331): 1-12.

Zaujan, N.A.M., Asma', A, Osman, M., Chee, H.Y., Raihana, N., Ithnin, S.S. \& Chin, C.P.Y 2021. Validity and reliability of a questionnaire on knowledge, attitude, practice and perception (KAP2) towards food poisoning and its prevention during dining out among consumers in Terengganu. Food Research, 5(4): 1-13. 
Zulkifly, M., Salleh, M., Hanafiah, M. \& Jamaluddin, M. 2013. assessing knowledge, attitude and practice (KAP) on food safety among food handlers in Universiti Teknologi Mara (UiTM), Shah Alam. Hospitality and Tourism, (November): 567-572.
Zyoud, S., Shalabi, J., Imran, K., Ayaseh, L., Radwany, N., Salameh, R. \& Al-Jabi, S. 2019. Knowledge, attitude, and practices among parents regarding food poisoning: A crosssectional study from Palestine. BMC Public Health, 19(1): 1-10. 